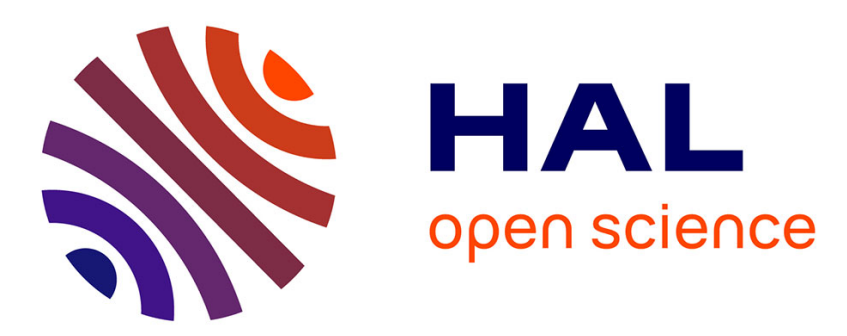

\title{
Impact of earthworms on the diversity of microarthropods in a vertisol (Martinique)
}

Gladys Loranger, Jean-François Ponge, Patrick Lavelle

\section{To cite this version:}

Gladys Loranger, Jean-François Ponge, Patrick Lavelle. Impact of earthworms on the diversity of microarthropods in a vertisol (Martinique). Biology and Fertility of Soils, 1998, 27 (1), pp.21-26. 10.1007/s003740050394. hal-00505427

\section{HAL Id: hal-00505427 \\ https://hal.science/hal-00505427}

Submitted on 30 Aug 2010

HAL is a multi-disciplinary open access archive for the deposit and dissemination of scientific research documents, whether they are published or not. The documents may come from teaching and research institutions in France or abroad, or from public or private research centers.
L'archive ouverte pluridisciplinaire HAL, est destinée au dépôt et à la diffusion de documents scientifiques de niveau recherche, publiés ou non, émanant des établissements d'enseignement et de recherche français ou étrangers, des laboratoires publics ou privés. 


\section{Impact of earthworms on the diversity of microarthropods in a vertisol} (Martinique)

\section{G. Loranger $\cdot$ J. F. Ponge $\cdot$ E. Blanchart $\cdot$ P. Lavelle}

G. Loranger ( ) Université des Antilles et de la Guyane, Faculté des Sciences Exactes et Naturelles, Laboratoire de Biologie et de Physiologie végétales, B.P. 592, 97159 Pointe à Pitre Cedex, Guadeloupe Fax: 05. 90. 93. 86. 81; e-mail: Gladys.Loranger@univ-ag.fr

J. F. Ponge Laboratoire d'Ecologie Générale, Muséum National d'Histoire Naturelle, 4 Avenue du Petit Château, F-91800 Brunoy, France

E. Blanchart Laboratoire Biologie et Organisation des Sols Tropicaux, ORSTOM, B.P. 8006, 97259 Fort de France, Martinique

P. Lavelle Laboratoire d'Ecologie des Sols Tropicaux, ORSTOM/Université Paris VI, 32 Avenue Henri Varagnat, F-93143 Bondy, France

\footnotetext{
Abstract In a study of a 15-year-old pasture in Martinique (French West Indies), abundance and organization of microarthropod communities were correlated with the spatial distribution of the earthworm Polypheretima elongata (Megascolecidae). In patches of high earthworm density (133 individuals $\mathrm{m}^{-2}$ ), microarthropod density was significantly higher (80000 individuals $\mathrm{m}^{-2}$ ) than in patches with few earthworms ( 31 worms $\mathrm{m}^{-2}$ and 49000 microarthropods $\mathrm{m}^{-2}$ ). The diversity of microarthropod communities followed a similar pattern, the Shannon index for Collembola communities being, respectively, 3.12 and 1.82 in and outside earthworm patches. These results suggest that mesofauna abundance and diversity might be at least partly determined by the activity of larger invertebrates, as a result of the dramatic effects that the latter group exerts upon soil structure, pore
} 
distribution and food resources.

Key words Microarthropods $\cdot$ Earthworms $\cdot$ Spatial distribution $\cdot$ Collembola $\cdot$ Biodiversity

\section{Introduction}

Soil macroinvertebrates (especially earthworms and termites) play a fundamental role in the dynamics of organic matter and structure of soils, at different scales of time and space (Lavelle et al. 1993, 1994). They markedly influence their environment by digging burrows and chambers, and building nests and mounds; they also produce aggregates of varying size and stability that affect the structure of soil. Microarthropods $(0.2-10 \mathrm{~mm}$ in length) have very limited capacities to burrow into the soil. As a result, their ability to move in the soil largely depends on their own size and on the size, shape, distribution and connectivity of the soil pore system. Microarthropods exhibit high abundance and diversity in the litter/soil system (Petersen and Luxton 1982). They play an important role as disseminators and activators of soil microorganisms, especially fungi, spores of which they transport on their bodies, or disseminate in their faecal pellets (Christen 1975).

This study aimed at testing the hypothesis that mesofauna diversity was influenced by the presence of larger invertebrates. Referred to as "nested biodiversity" (Giller et al. 1997; Lavelle 1997), this hypothesis was tested in a pasture of southern Martinique (West Indies) where macro-invertebrate communities were represented mainly by a community largely dominated by the earthworm Polypheretima elongata (Barois et al. 1988). This species is distributed in patches of 20-40 m diameter, the position of which vary from year to year (Rossi et al. 1997). After such patches had been located in the field using a specific sampling design, communities of microarthropods were compared in-and outside a patch. Collembola were identified at the species level and individuals were measured to check for possible selection due to earthworm-induced macroporosity.

\section{Materials and methods}


The study was carried out at the SECI experimental site (Station d'Essais en Cultures Irriguées, Conseil Général de la Martinique), located at Saint-Anne, south eastern Martinique. This area receives an annual rainfall of 1000$2000 \mathrm{~mm}$ (average $1400 \mathrm{~mm}$ ).

The study plot is an old sugarcane plantation that was transformed into a pasture 15 years before the present study. The grass Digitaria decumbens was the only species cultivated in this pasture, where it formed a dense, continuous plant cover. The plot was regularly grazed by sheep and cows, and periodically watered and fertilized. The only earthworm species found in our plot was $P$. elongata, an endogeic worm with a pantropical distribution (Lavelle 1981), which commonly ingests soil rich in organic matter. At Saint-Anne, earthworm populations have a biomass of up to $3600 \mathrm{~kg}$ (fresh weight) $\mathrm{ha}^{-1}$ (Barois et al. 1988). Under optimal conditions, the fresh weight and density of adults can reach $6 \mathrm{~g}_{\text {individual }}{ }^{-1}$, and 100 individuals $\mathrm{m}^{-2}$, respectively (Lavelle et al. 1992, 1994). This species does not cast abundantly at the soil surface, most ingested soil being egested within burrows. At our study site, this species is distributed in patches (Rossi et al. 1997) of 20-40 m in diameter.

The soil is a calco-magneso-sodic vertisol characterized by $\mathrm{Mg}^{2+} / \mathrm{Ca}^{2+}=1.5 \%$ and $\mathrm{Na}^{+} /$cation exchange capacity $=16 \%$. The soil profile examined in a nearby long-term pasture (Kulesza 1994) showed that the top 25 $\mathrm{cm}$ (plough layer) was a brown clay ( $>60 \%$ smectite), with a prismatic structure, breaking to form coarse polyhedral aggregates. Biological activity is high, as shown by the abundance of earthworm casts and burrows, and roots. The organic carbon content varies from $35 \%$ in the upper $10 \mathrm{~cm}$ to $15 \%$ at the bottom of the soil profile.

A preliminary sampling was designed to localize zones with high and low earthworm densities. Earthworms were hand-sorted from 85 blocks of soil $(30 \mathrm{~cm} \times 30 \mathrm{~cm} \times 30 \mathrm{~cm})$ taken at regular $4-\mathrm{m}$ intervals along transect lines, then counted and weighed. Four points with high density and four with low density were chosen in order to delineate two zones in the pasture (Table 1). Each zone had a surface of $16 \mathrm{~m}^{2}(4 \mathrm{~m} \times 4 \mathrm{~m})$. Microarthropods were sampled inside two $1.2 \mathrm{~m} \times 2 \mathrm{~m}$ quadrates placed at the centre of each zone. Sixty regularly spaced cores, $10 \mathrm{~cm} \times 10 \mathrm{~cm}$ in cross-section and $3 \mathrm{~cm}$ in depth, were taken in each zone.

Soil mesofauna were extracted in Berlese funnels. Losses of water and harvest of animals were known to be at a maximum at $40^{\circ} \mathrm{C}$ for the studied vertisol (Loranger 1995), so this temperature was chosen for the 
extraction, which was completed within $48 \mathrm{~h}$. In the climatic conditions prevailing at the time of sampling, 75\% of the total micro-arthropod community was present in the top $3 \mathrm{~cm}$ of soil (Loranger 1995), and sampling was limited to this depth. Sampling and extraction were achieved during the dry season (under irrigation) in April and May 1995.

Microarthropods were counted under a binocular lens and classified into 26 taxa.

Collembola were sorted and identified at the species level in ten samples randomly taken in each zone. Animals were mounted in chloral-lacto-phenol $(25 \mathrm{ml}$ phenol, $50 \mathrm{~g}$ chloral hydrate, $25 \mathrm{ml}$ lactic acid) and observed under a microscope at a magnification of $\times 400$. The size of each individual was determined using the binocular lens. Four size classes were defined: class 1, $1.5 \mathrm{~mm}$, i.e. epigeic, with developed appendages (antennae, legs and furcula); class 2, 1-1.5 mm; class 3, 0.7-1 mm; class 4, 0.5-0.7 mm, endogeic species with short appendages.

Data sets were processed using analysis of variance (ANOVA) (Sokal and Rohlf 1995) and correspondence analysis (CA) (Greenacre 1984). Densities for each animal group were reweighted (SD=1) and focused (mean 10 ). Each group was represented on the graphs by two points: one for higher densities (original data, $\mathrm{x}$, transformed as mentioned above), the other for lower densities (elaborated data, calculated as 20-x, giving similar SD and mean). They were denoted by upper case and lower case three-letter codes, respectively (Table 2). A peculiarity of CA is the projection of samples and variables on the same graph, variables located within a group of samples being typical for this group. However, for clarity we did not include all 120 samples. In order to help interpretation of the factorial axes, water content (HUM and hum for higher and lower values, respectively), abundance $(\mathrm{EW}+)$ and scarcity (EW-) of earthworms were put as additional variables, i.e. projected even though not included in the matrix to be analysed (supplementary or passive data).

In order to compare communities of Collembola in the two zones, a sign test (Siegel 1956) was used. This test allowed us to determine the species which were typical of each zone.

Another CA was performed on the 18 Collembola species. Samples were denoted by V1 to V10 inside the earthworm patch and SV1 to SV10 outside. Active variables were the densities of the 18 Collembola species. Four passive variables were added: abundance (EW+) and scarcity (EW-) of earthworms, higher (P) and lower 
(m) total densities of Collembola.

CA were completed by ascending hierarchical classification (AHC) (Bouchon 1992) in order to find homogeneous groups. The distance used was the Euclidean distance calculated from the factorial coordinates of CA.

ANOVA were performed on densities of each taxa and on each size class of Collembola in order to compare the two studied zones.

In each zone, the diversity of collembolan communities was evaluated by the Shannon index (Ish) and equitability (E) (Pielou 1966):

$\mathrm{Ish}=-\Sigma p_{\mathrm{i}} \log _{2} p_{\mathrm{i}}$

where $p_{\mathrm{i}}=$ relative abundance of species, $\mathrm{i}$

$E=\mathrm{Ish} / \log _{2} S$

where $S=$ number of species

\section{Results}

In the earthworm patch, 24 groups of microarthropods were present; only 20 were found outside the patch (Table 2). Microarthropod density was $80000 \pm 3870$ individuals $\mathrm{m}^{-2}$ in the earthworm patch, and $49000 \pm 2320$ individuals $\mathrm{m}^{-2}$ outside, i.e. about half their density in the patch.

Acari, Collembola and ants were the most abundant groups. In the patch, $72.8 \%$ of arthropods were Acari, $16.4 \%$ Collembola and $7.8 \%$ ants; other groups represented only $3 \%$ of the total sampled fauna. In the zone with low earthworm density, $74.1 \%$ of arthropods were Acari, $18.4 \%$ Collembola and $6.1 \%$ ants, other groups amounted to $4.4 \%$ of the sampled fauna. Aphids, Geophila, Pauropoda, Curculionidae, Araneidae and Polyxenida were absent from the zone with few earthworms.

Axes $1-3$ of CA accounted for $16.7 \%, 11 \%$ and $7.4 \%$ of the total variance, respectively. Axis 1 (Fig. 1) 
opposed low to high density communities. On axis 2 the positions of Araneidae, Heteroptera larvae, Diptera larvae, Coleoptera larvae and Polyxenida were in opposition to those of ants and ants larvae. We did not need to examine axis 3. AHC homogeneous groups of taxa in relation with CA (Fig. 1). ANOVA (Table 2) showed a high number of significant differences between the two zones. Globally, the highest arthropod densities were observed in the earthworm patch, but differences could not be tested accurately in the case of groups with lower densities such as Thysanoptera, Carabidae, Scarabaeidae, Staphylinidae, Curculionidae, Pauropoda, Homoptera larvae and Diptera larvae. Heteroptera nymphs and Coleoptera larvae, although more abundant, did not present any significant differences. Adult Heteroptera and Hemiptera nymphs were the only groups with significantly higher abundance in the zone with low earthworm density. The taxonomical richness (number of taxa present in the communities), was significantly higher in the earthworm patch, when tested by ANOVA $(P<0,001 \%)$.

The water content in the top $3 \mathrm{~cm}$ of the soil was significantly higher in the zone with low earthworm density $(19.05 \% \pm 4.4$ in the patch and $30.50 \% \pm 1.62$ outside, as assessed by ANOVA).

A total of 18 collembolan species were found in the pasture. All 18 species were present in the earthworm patch and only 16 outside the patch. A sign test (Siegel 1956) was used to indicate significant differences between the two communities (Table 3). Comparison of signs showed that (Lepidocyrtus sp. 3) was the only species typical of the zone with low earthworm density. Axis 1-3 of CA accounted for $25.7 \%, 16.2 \%$ and $11.5 \%$ of the total variance, respectively. Axis 1 (Fig. 2) showed the differences between the two zones. Axis 1 and axis 2 combined opposed the zone with a high earthworm density to the zone with a low earthworm density. Axis 2 indicated a higher diversity of collembolan communities in the zone with a high earthworm density. We did not need to examine axis 3. AHC indicated the presence of different homogeneous groups (Fig. 2). ANOVA on size classes of Collembola showed that large individuals of classes 1 and 2 were significantly more abundant in the zone with a high earthworm density. This analysis did not show any difference for small individuals of classes 3 and 4. Diversity and equitability of the collembolan community were higher in the earthworm patch than outside (Table 4).

\section{Discussion}


The spatial distribution of microarthropod populations may be influenced by many factors. Among them, soil depth (arthropod populations are concentrated generally in the top $5 \mathrm{~cm}$ of soil), $\mathrm{pH}$, water content, food resources (bacteria, fungi, plant fragments) and pore size have been highlighted (Boudjema et al. 1991; Ponge 1993).

In the tropical pasture studied, the density of microarthropods was higher in a zone with a high earthworm density than in a nearby zone with low earthworm populations. Similar results were found in studies undertaken in temperate climates by Hamilton and Sillman (1989) and Marinissen and Bok (1988). Three main hypotheses can be put forward to explain this phenomenon:

$>1$. Trophic properties. Food resources made available by earthworm activities may strongly increase the abundance of microarthropods. Earthworms may partly digest tannin-protein complexes (Zhang et al. 1993) and enhance the development of soil bacteria by mixing litter with mineral matter (Went 1963), thus favouring bacterial-feeding animals living near the surface.

>2. Improved circulation in the pore space. Macropores created by earthworms may be considered as a habitat for a number of microarthropods (Haukka 1991). Indeed, animal groups most favoured by the presence of earthworms (Isopoda, aphids, Coleoptera; see Table 2) were large invertebrates. In the presence of earthworms, pores of a medium size that most mesofauna groups prefer (Vannier 1975) are numerous (Hamilton et al. 1988). Marinissen and Bok (1988) also hypothesized that the presence of a large number of interconnected pores, due to the influence of earthworms, could increase the density of Collembola.

>3. Water regime. Soil water content in the upper $3 \mathrm{~cm}$ was higher in the zone with few earthworms. Given the periodic watering of the pasture at the time of the study, excess water in the zone poor in earthworms could also be a factor limiting the development of microarthropod communities. In this case, the absence of macropores favours only aquatic and subaquatic species such as amoebae, nematodes and rotifers (Vannier 1987). In the presence of burrowing earthworm species, drainage of the soil is improved to a great extent (Springett et al. 1992).

The authors are aware of the fact that the positive action of earthworms upon microarthropods can be demonstrated only experimentally, and the present results give only circumstantial evidence of this phenomenon. 
Indirect effects of irrigation might have been detrimental both to earthworms and microarthropods. Nevertheless, our argument against such a possible cause for the observed trends is based on the fact that patches of high earthworm density vary from year to year, and are not correlated with the horizontal distribution of soil physicochemical properties such as particle-size distribution, as has been demonstrated for the same site by Rossi et al. (1997). Moreover, the increase in the size of collembolan species in the earthworm patch can be compared with the increase in macroporosity due to the burrowing activity of $P$. elongata.

In conclusion density and diversity of microarthropod communities were higher in a zone with a high earthworm density than in an adjacent area with a depleted earthworm population. The development of microarthropods is thus favoured by ecological conditions associated with the presence and activity of earthworms. Earthworms provide smaller organisms with additional food resources (micro-organisms of the drilosphere, cutaneous mucus, comminuted and partly digested litter in casts) and create specific microhabitats (interconnected macropores). The spatial distribution of earthworms could be governed by different factors, and most probably determines that of microarthropods.

Acknowledgements This study was partly funded by the French Ministry of Environment (Programme SOFT). We are grateful to the Conseil General de la Martinique for allowing the study in the experimental station (SECI). We also greatly acknowledge the technicians of the ORSTOM BOST laboratory for field assistance.

\section{References}

Barois I, Cadet P, Albrecht A, Lavelle P (1988) Système de culture et faune des sols. Quelques données. In: Feller C (ed) Fertilité des sols dans les agricultures paysannes caribéennes. Effet des restitutions organiques. Rapport final de projet CEE. ORSTOM, Fort de France, Martinique, pp 85-96

Bouchon C (1992) Logiciel ECODATA. University of the Antilles, Guyane, F-97159 Pointe à Pitre, Guadeloupe

Boudjema G, Julien JM, Sarkar S, Cancela da Foncesa JP (1991) Etude par l'analyse statistique multilinéaire de l'impact des facteurs physico-chimiques sur l'abondance des microarthropodes édaphiques d'une forêt 
de mousson en Inde orientale. Rev Ecol Biol Sol, 28:303-322

Christen A (1975) Some fungi associated with collembola. Rev Ecol Biol Sol 12:723-728

Giller KE, Beare MH, Lavelle P, Izac AM, Swift MJ (1997) Agricultural intensification, soil biodiversity and ecosystem function. Appl Soil Ecol 6:3-16

Greenacre MJ (1984) Theory and applications of correspondence analysis. Academic Press, London

Hamilton WE, Sillman DY (1989) Influence of earthworm middens on the distribution of soil microarthropods. Biol Fertil Soils 8:279-284

Hamilton WE, Dindal DL, Parkinson CM, Mitchell MJ (1988) Interaction of earthworm species in sewage sludge-amended soils microcosms: Lumbricus terrestris and Eisenia fetida. J Appl Ecol 25:847-852

Haukka J (1991) Spatial distribution and formation of earthworm burrows. Pedobiologia 35:175-178

Kulesza V (1994) Evolution de la structure des vertisols de la Martinique en fonction du système de culture. Mémoire de fin d'année I.S.T.O.M. ORSTOM Martinique

Lavelle P (1981) Stratégies de reproduction chez les vers de terre. Acta Oecol. Oecol Gen 2:117-133

Lavelle P (in press) Diversity of soil fauna and ecosystem function. Biol Int

Lavelle P, Blanchart E, Martin E, Spain AV, Martin S (1992) Impact of soil fauna on the properties of soils in the humids tropics. In: Segoe S (ed) Myths and sciences of soils of the tropics. Soil Sci Soc Am Spec Publ 29:157-185

Lavelle P, Blanchart E, Martin A, Martin S, Spain A, Toutain F, Barois I, Schaefer R (1993) A hierarchical model for decomposition in terrestrial ecosystems: applications to soils of the humid tropics. Biotropica 25:130-150

Lavelle P, Dangerfield M, Fragoso C, Eschenbrenner V, Lopez-Hernandez D, Pashanasi B, Brussaard L (1994) The relationship between soil macrofauna and tropical soil fertility. In: Woomer PL, Swift MJ (eds) The biological management of tropical soil fertility. Wiley, New York, pp 137-169 
Loranger G (1995) Distribution spatiale de la mésofaune dans des vertisols martiniquais. Influence du mode d'exploitation du sol et des vers de terre. Mémoire de stage de DEA, University of Nancy I

Marinissen JCY, Bok J (1988) Earthworm-amended soil structure: its influence on Collembola populations in grassland. Pedobiologia 32:243-252

Petersen H, Luxton M (1982) A comparative analysis of soil fauna populations and their role in decomposition processes. Oikos 39:288-388

Pielou EC (1966) The measurement of diversity in different types of biological collections. J Theor Biol 13:131144

Ponge JF (1993) Biocenoses of collembola in Atlantic temperate grass-woodland ecosystems. Pedobiologia $37: 223-244$

Rossi JP, Lavelle P, Albrecht A (1997) Relationship between spatial pattern of the endogeic earthworm Polypheretima elongata and soil heterogeneity. Soil Biol Biochem 29:485-488

Siegel S (1956) Nonparametric statistics for the behavorial sciences. McGraw-Hill, New York

Sokal R, Rohlf JF (1995) Biometry. The principles and practice of statistics in biological research. Freemon, New York

Springett JA, Gray AJ, Reid JB (1992) Effect of introducing earthworms into horticultural lands previously denuded of earthworms. Soil Biol Biochem 24:1615-1622

Vannier G (1975) Etude in situ du retour des microarthropodes sur des fractions de sol de granulométrie différente. Bull Ecol 6:87-98

Vannier G (1987) The porosphere as an ecological medium emphasized in Professor Ghilarov's work on soil animal adaptations. Biol Fertil Soils 3:39-44

Went JC (1963) Influence of earthworms on the number of bacteria in the soil. In: Doeksen J, Van der Drift J (eds) Soil organisms. North-Holland, Amsterdam, pp 260-265 
Zhang BG, Rouland C Lattaud C, Lavelle P (1993) Activity and origin of digestive enzymes in the gut of the tropical earthworm Pontoscolex corethrurus. Eur J Soil Biol 29:7-11 


\section{Legends of figures}

Fig. 1 Correspondence analysis (CA) on the microarthropod fauna. Projection in the plane of axes 1 and 2. For codes, see Table 2

Fig. 2 CA on collembolan species. Projection in the plane of axes 1 and 2. For codes see, Table 3 
Table 1 Total densities and biomasses of earthworms in the two sub-plots studied (mean \pm SE, $n=4$ )

High earthworm density Low earthworm density

\begin{tabular}{lll}
\hline Total density (individuals $\mathrm{m}^{-2}$ ) & $133 \pm 4$ & $31 \pm 7$ \\
Total biomass $\left(\mathrm{g} \mathrm{m}^{-2}\right)$ & $90 \pm 5$ & $24 \pm 8$ \\
\hline
\end{tabular}


Table 2 Total densities (individuals $\mathrm{m}^{-2}$ ) of mesofauna in zones with high and low earthworm densities (mean $\pm \mathrm{SE}, n=60)$ compared by analysis of variance

\begin{tabular}{llll}
\hline Microarthropods (codes) & High earthworm density & Low earthworm density & Significance \\
\hline Collembola (COL) & $13312 \pm 720$ & $8927 \pm 731$ & $* * *$ \\
Formicoidea (FOU) & $6378 \pm 2024$ & $2958 \pm 1161$ & $* * *$ \\
Isopoda (ISO) & $442 \pm 54$ & $42 \pm 13$ & $* * *$ \\
Aphids (APH) & $605 \pm 270$ & 0 & $* * *$ \\
Dermaptera (DER) & $108 \pm 15$ & $102 \pm 44$ & $*$ \\
Thysanoptera (TRI) & $2 \pm 2$ & $7 \pm 4$ & $\mathrm{~ns}$ \\
Heteroptera (HET) & 0 & $218 \pm 49$ & $* * *$ \\
Carabidae & $3 \pm 3$ & $2 \pm 2$ & $\mathrm{~ns}$ \\
Scarabaeidae & $8 \pm 4$ & $5 \pm 4$ & $\mathrm{~ns}$ \\
Staphylinidae & $2 \pm 2$ & $3 \pm 2$ & $\mathrm{~ns}$ \\
Curculionidae & $2 \pm 2$ & 0 & $\mathrm{~ns}$ \\
Other Coleoptera & $118 \pm 20$ & $17 \pm 6$ & $* * *$ \\
Acari (ACA) & $59142 \pm 2297$ & $35980 \pm 1368$ & $* * *$ \\
Araneidae (ARA) & $7 \pm 3$ & 0 & $* * *$ \\
Geophila (GEO) & $42 \pm 9$ & 0 & $* * *$ \\
Lithobia (LIT) & $68 \pm 10$ & $23 \pm 7$ & $\mathrm{~ns}$ \\
Pauropoda (PAU) & $15 \pm 9$ & 0 & $* * *$ \\
Polyxenida (POL) & $72 \pm 24$ & 0 & $* *$ \\
Hemiptera nymphs (LHM) & $5 \pm 4$ & $85 \pm 37$ & $\mathrm{~ns}$ \\
Homoptera nymphs (LHO) & 0 & $2 \pm 2$ & $\mathrm{~ns}$ \\
Heteroptera nymphs (LHT) & $23 \pm 8$ & $33 \pm 9$ & $* * *$ \\
Formicoidea larvae (LFO) & $538 \pm 168$ & $123 \pm 79$ & $\mathrm{~ns}$ \\
Coleoptera larvae (LCO) & $35 \pm 10$ & $18 \pm 7$ & $\mathrm{~ns}$ \\
Diptera larvae (LDI) & $15 \pm 6$ & $7 \pm 3$ & $* * *$ \\
Thysanoptera nymphs (LTR) & $107 \pm 18$ & $22 \pm 7$ & $* * *$ \\
Other insect larvae (LAU) & $172 \pm 28$ & $10 \pm 5$ & \\
\hline$* * * P<0.001 * * * 0.01, * P<0$ & $0.05 ; n s$ (a) & &
\end{tabular}

*** $P<0.001, * * P<0.01, * P<0.05 ; n s$ non-significant 
Table 3 Total number of Collembola collected in ten samples, taken randomly in the two studied zones; relative abundance of species (\%). For the sign test (Siegel 1956): total number of species, $n=18$; number of negative signs, $x=2$; significance $P<0.001 . \square$ Collembolan species more abundant in the zone with low earthworm density

\begin{tabular}{llll}
\hline & $\begin{array}{l}\text { High earthworm } \\
\text { density }\end{array}$ & $\begin{array}{l}\text { Low earthworm } \\
\text { density }\end{array}$ & $\begin{array}{l}\text { High density }>\text { low } \\
\text { density }\end{array}$ \\
\hline Acherontiella sp. 1 (Asp1) & $5(0.5 \%)$ & 0 & + \\
Acherontiella sp. 2 (Asp2) & $70(6.7 \%)$ & $25(4.3 \%)$ & + \\
Brachystomella sp. (Bsp) & $16(1.5 \%)$ & 0 & + \\
Cryptopygus cf. separata (Cse) & $370(35.4 \%)$ & $323(55.4 \%)$ & + \\
Crytopygus sp. (Csp) & $35(3.3 \%)$ & $5(0.8 \%)$ & + \\
Cyphoderus cf. similis (Csi) & $20(1.9 \%)$ & $5(0.8 \%)$ & + \\
Folsomides americanus (Fam) & $58(5.5 \%)$ & $9(1.5 \%)$ & + \\
Isotomiella minor (Imi) & $20(1.9 \%)$ & $5(0.8 \%)$ & + \\
Isotomodes sp. (Isp) & $2(0.2 \%)$ & $3(0.5 \%)$ & - \\
Lepidocyrtus sp. 1 (Lsp1) & $112(10.7 \%)$ & $54(9.3 \%)$ & + \\
Lepidocyrtus sp. 2 (Lsp2) & $9(0.9 \%)$ & $1(0.2 \%)$ & + \\
Lepidocyrtus sp. 3 (Lsp3) & $2(0.2 \%)$ & $13(2.2 \%)$ & - \\
Pseudosinella sp. (Psp) & $106(10.1 \%)$ & $21(3.6 \%)$ & + \\
Salina banksi (Sba) & $1(0.1 \%)$ & $1(0.2 \%)$ & 0 \\
Seira bipunctata (Sbi) & $46(4.4 \%)$ & $34(5.8 \%)$ & + \\
Seira sp. (Ssp) & $76(7.3 \%)$ & $33(5.7 \%)$ & + \\
Xenylla sp. 1 (Xsp1) & $97(9.3 \%)$ & $50(8.7 \%)$ & + \\
Xenylla sp. 2 (Xsp2) & $1(0.1 \%)$ & $1(0.2 \%)$ & 0 \\
\hline
\end{tabular}


Table 4 Diversity (Shannon index) and equitability of collembolan communities in the two studied zones

\begin{tabular}{lll}
\hline & $\begin{array}{l}\text { Diversity } \\
\text { (Shannon index) }\end{array}$ & Equitability \\
\hline High earthworm density & 3.12 & 0.75 \\
Low earthworm density & 1.82 & 0.45 \\
\hline
\end{tabular}




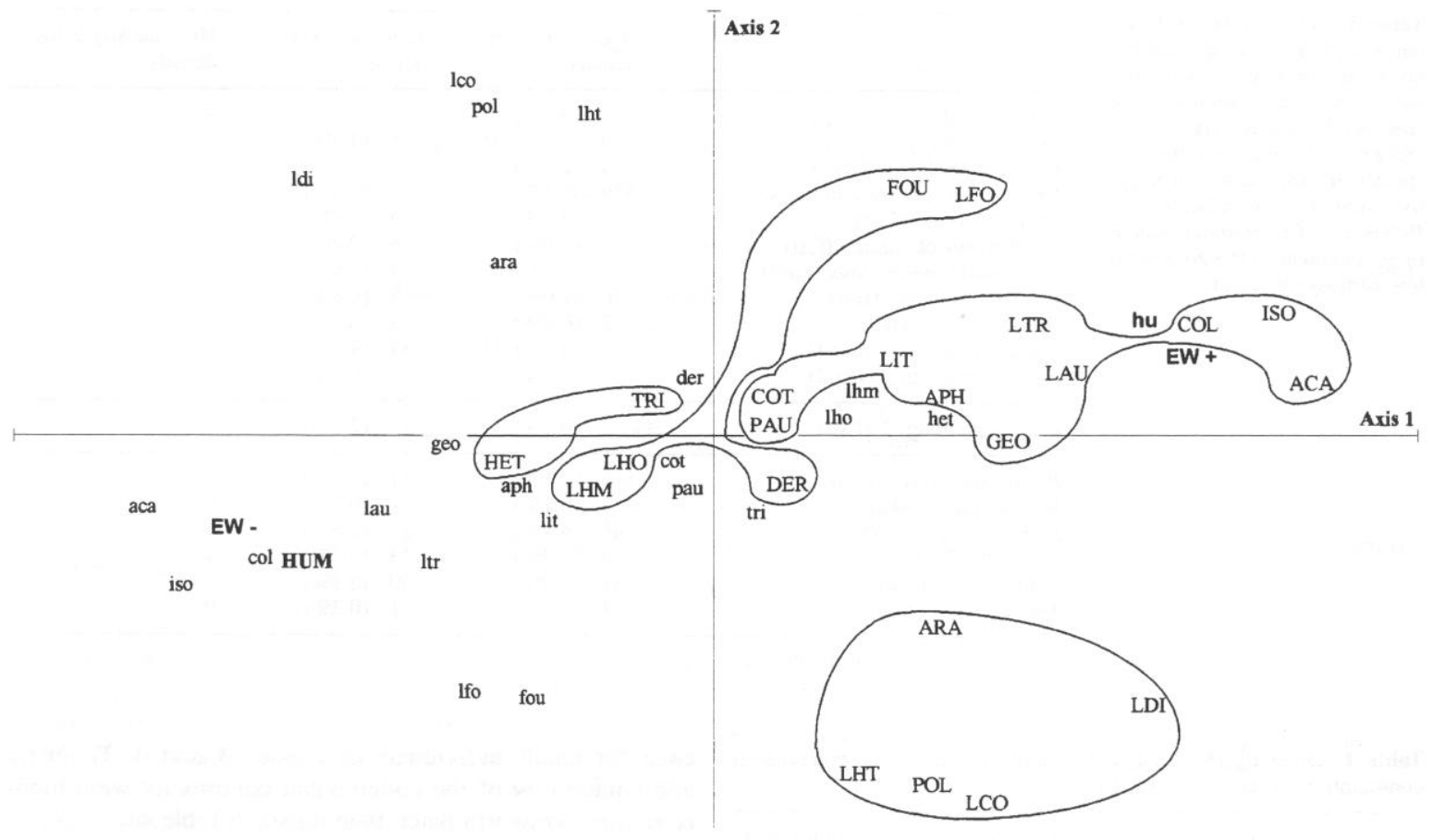

Fig. 1 


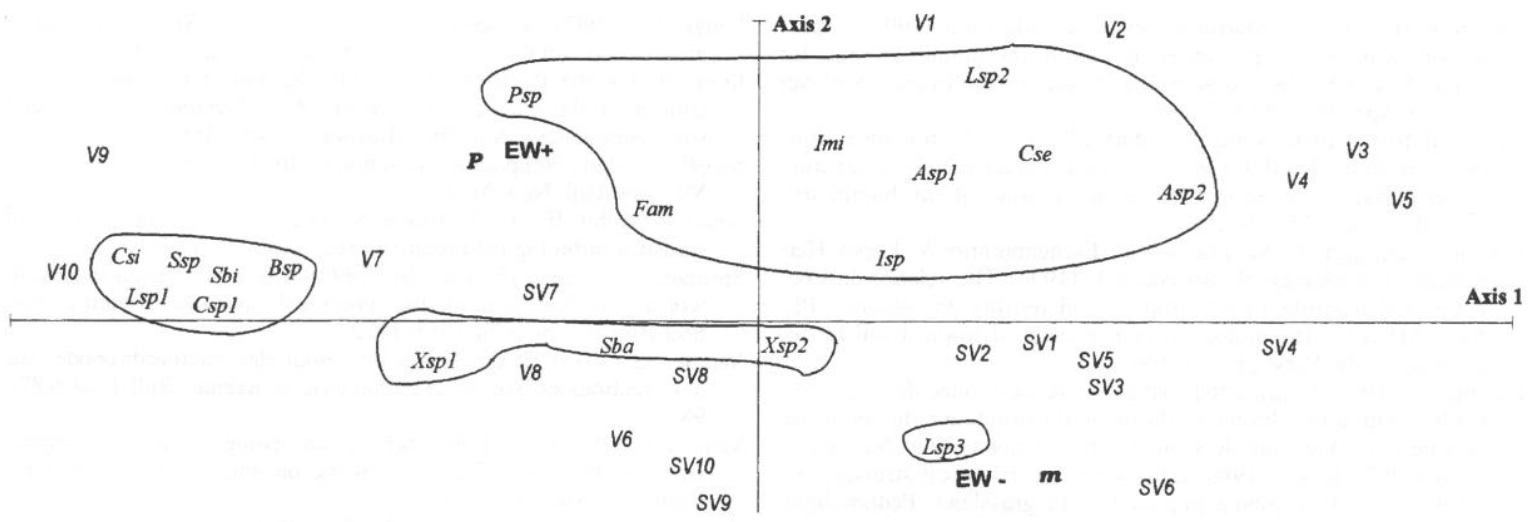

Fig. 2 